\title{
The effect of white clover (Trifolium repens L.) and nitrogen fertilisation on biomass production, morphology, chemical composition and weed infestation of willow (Salix viminalis L.)
}

Waldemar Helios ( $\sim$ waldemar.helios@upwr.edu.pl )

Uniwersytet Przyrodniczy we Wrocławiu https://orcid.org/0000-0001-8179-2916

\section{Research Article}

Keywords: undersowing cultivation, basket willow, white clover, nitrogen fertilization, chemical composition

Posted Date: March 10th, 2021

DOl: https://doi.org/10.21203/rs.3.rs-230626/v1

License: (9) This work is licensed under a Creative Commons Attribution 4.0 International License. Read Full License 


\section{Abstract}

The study was aimed at determining the effect of nitrogen fertilization and white clover on biomass yield weed infestation, morphology, and chemical composition of willow. A field experiment was established in 2013 at Wroclaw University of Environmental and Life sciences (Poland). The results showed that the number and dry mass of weeds per $1 \mathrm{~m} 2$, the number of willow shoots and the fresh weight yield of willow were smaller where clover was sown. The plants were found to be higher after applying nitrogen fertilization. The dry mass yield and shoot diameter did not depend on the cultivation method. Nitrogen fertilization increased the content of ash, and in undersowing cultivation the willow stems had higher nitrogen content than in monoculture. On average, the phloem had 5.6 times higher crude ash content and 4.6 times higher nitrogen content than wood. The ratio of wood dry mass to phloem dry mass in undersowing cultivation and nitrogen fertilization was 3.97:1, and 3.91:1 for the control. On the basis of the conducted research, it can be concluded that in the first years after planting the undersowing growing of willow with white clover can be an alternative to plantations fertilized and non-fertilized with nitrogen.

\section{Introduction}

Short rotation woody crops (SRWC) are important in ensuring a more secure energy future worldwide [1]. In Additionally the cultivation of energy crops including SRWC reduces soil erosion [2,3] and leads to an increase in humus content and soil structure improvement [4, 5]. Energy crops reduce carbon dioxide emissions both by replacing fossil fuels and by immobilizing organic carbon in soil [6-10]. The cultivation of these plant can forestall deforestation [10]. In the near future, biomass obtained from SRWC will become more important and beneficial [11].

Of all the species cultivated for energy purposes, willow is cultivated in the greatest area in Northern Europe $[12,11,6]$. Due to the numerous environmental benefits, the area of willow cultivation is predicted to grow rapidly over the next decades [13]. This plant is characterized by high biomass increments [14], can be easily propagatet by cuttings [13] and due to its natural occurrence in Poland it is perfectly adapted to the climatic conditions that occur in this country.

Soil erosion and nitrogen leaching on SRWC plantations is lower than on arable land. Nevertheless, it occurs, [15-19]. One way to reduce nitrogen leaching may be to sow white clover during planting energy crops. This plant as a cover crops grown via intercropping with the main crop maintain soil fertility, and reduce the use of pesticides and mineral fertilisers and minimalize cultivation costs. McLaughlin and Walsh [9] stated that the cultivation of ground cover plants in the field trial with poplars prevented the leaching of fertilizer and nitrogen from the soil. The economic benefits (or losses) from fertilization largely depend on the cost of fertilization and the price received for biomass [20].

Willow is prone to weed infestation in the initial years after planting. It should also be noted that in the first vegetation period weeds use nitrogen more efficiently than willow and nitrogen fertilization does not always contribute to the yield increase [21]. In the first year after planting, weeds can limit willow growth 
from $50 \%$ to $95 \%$. Currently, recommendations for the establishment of SRWC involve the use of herbicides and tillage in the autumn in order to control weeds [22].

Theoretically, undersowing of willow together with white clover can bring a number of benefits. Monoclonal growing systems are considered to be vulnerable to pathogen adaptations. The cultivation of cover crops results in an improvement in biodiversity on willow plantations and may decrease the pressure on willow from pathogens. The compact cover of white clover plants, whose roots overgrow the soil, prevents erosion. Weed infestation also decreases, which is particularly beneficial for willows when there are high and climbing weeds on the plantation [22-24]. The symbiotic nitrogen fixation by bacteria coexisting with white clover increases the amount of nitrates in the soil. White clover can supply $100 \mathrm{~kg}$ $\mathrm{ha}^{-1}$ of atmospheric nitrogen $[15,25,26]$.

However, white clover competes with willow for nutrients. It has been found that live cover plants integrated with woody plants during the establishment of plantations compete with each other for moisture, and possibly light, resulting in reduced growth leaching $[27,28]$. Other studies have not confirmed these observations [22]

The aim of this study was to compare differences in yield, morphology and chemical composition of willow fertilized and unfertilized with nitrogen and undersowing cultivation (willow with white clover) and then to compare these for 2013-2017. In the working hypothesis it was assumed that in undersowing cultivation with white clover can replace fertilization with nitrogen. The results of the research can be particularly useful for biomass producers. They can also be an inspiration for additional research for the needs of willow growers.

\section{Materials And Methods}

\section{Study Sites}

A field trial was conducted at Wroclaw University of Environmental and Life Sciences in Poland between 2013-2017. The field trial was located in a suburban area at a distance of $10 \mathrm{~km}$ north west of the centre of Wroclaw. The field plots were located at an altitude of $147 \mathrm{~m}$ above sea level, in the catchment area of the river Dobra, a right-bank tributary of the river Widawa. The geographical position is defined by the following coordinates: $51^{\circ} 10^{\prime} \mathrm{N}, 17^{\circ} 07^{\prime} \mathrm{E}$.

\section{Soil Conditions}

The field experiments were conducted on a light soil defined as very light alluvial soil, on loose sand and sandy gravel. Each year, soil samples (from each plot) were analysed. Samples were taken at a depth of $0-30 \mathrm{~cm}$ at the start of the vegetation period. Analysis were performed according to the following methods:

the soil reaction $(\mathrm{pH} / \mathrm{KCl})$ by the potentiometric method 
the available forms of potassium and phosphorus by Egner-Rhiem method

magnesium by Schachtschabel method

The soil is visibly alkaline, the content of phosphorus ranges from medium to high, and potassium from high to very high, and the content of $\mathrm{Mg}$ is medium [see supplementary online material Table S1].

Weather Conditions

The research was conducted in one of the warmest of Lower Silesia's regions. In the first half of the 20th century the average annual air temperature was $8.6^{\circ} \mathrm{C}$, the average temperature of the vegetation period (IV-IX) was $14.7^{\circ} \mathrm{C}$. The groundwater level was $85 \mathrm{~cm}$ below the ground level. The mean annual temperature during the study was higher than the long-term trend. The monthly and annual average precipitation sums varied. The lowest precipitation was reported in 2015. Specific temperature and precipitation breakdown are described in Tables S2 and S3 [see supplementary online material].

Material and Management Practices

This study was conducted in an experiment with a Salix viminalis var. gigantea (1047 willow clone). This variety is intended for biomass producers. It was planted obtained from a nearby plantation (planted in 2010) immediately before planting. Willows were planted in a twin row configuration. Cuttings $20 \mathrm{~cm}$ in length were planted in $100 \mathrm{~cm}$ wide interrows with $60 \mathrm{~cm}$ spacing (16,700 cuttings per hectare). White clover of the Romena cultivar was sown in the amount of $10 \mathrm{~kg} \mathrm{ha}^{-1}$ (hand-sown during plantation setup). The willow plants were not harvested after the first vegetation period and the clover was not mown during the studied period. For the first two years in tested undersowing cultivation clover covered about $95 \%$ of the area. Clover dying was observed because of little access to light and drought in the third year of the experiment. To determine the yield, willow plants were harvested after fifth vegetation periods. The chemical composition was determined on four and five-year-old plants.

The pre-forecrop was winter oil seed rape (OSR) and the forecrop was fallow land. The majority of weed species in the year before the plantation was identified, and these included: Elymus repens (L.) Gould., Viola arvensis Murr. and Thlaspi arvense L. In July and September 2012, two sprays of Roundup 360 SL herbicide at a dose of $5 \mathrm{I} \mathrm{ha}{ }^{-1}$ were applied and autumn ploughing was performed. In spring, the field was evened out with a cultivator. After these treatments, weeds were no longer controlled until the end of the experiment.

Mineral fertilizers were applied annually in the spring in April. Fertilized plots annually received $35.2 \mathrm{~kg} \mathrm{P}$ $\mathrm{ha}^{-1}$ and $83 \mathrm{~kg} \mathrm{~K} \mathrm{ha}^{-1}$ as urea, treble superphosphate and muriate of potash. Urea (50 kg N ha-1) was applied on nitrogen fertilized plots.

Measurement 
The number and dry mass of weeds was assessed each year in June. A $50 \mathrm{~cm}$ x $50 \mathrm{~cm}$ metal frame was placed on the ground between the rows at four places within each plot in the treatment. The numbers and species of weeds were recorded inside each frame [see supplementary online material Fig. S1]. The weed biomass was assessed by weighing their fresh mass. The dry matter of the weeds was established by the drying method. The fresh mass of weeds was dried at $60^{\circ} \mathrm{C}$ for 24 hours and then for five hours at $105^{\circ} \mathrm{C}$. After harvest in December 2017, absolute dry mass yield and water content in plants were determined based on 4 randomly chosen shoots from every plot. The shoot fragments were cut at a distance of 20 $\mathrm{cm}$ on both sides of the gravity centre point and subsequently dried at $60^{\circ} \mathrm{C}$ for 1 week until constant weight was reached, and then dried for 5 hours at $105^{\circ} \mathrm{C}$ (modified norm PN-R-04013:1988). The phloem and wood were separated by hand. After debarking the shoots, the phloem and wood were dried, milled and weighed in the same way as the shoot fragments and then chemically analysed. The weight of fresh and dry stem pieces was determined with an accuracy of $0.01 \mathrm{~g}$. Total shoot dry weight per plot was calculated by multiplying the total fresh weight of all sampled shoots for each net plot by the dry matter content. Plant shoot dry weight was calculated as total shoot dry weight per net plot divided by the number of living plants in each net plot.

At the beginning and end of the vegetation period, the diameter and height of the main shoot were measured $20 \mathrm{~cm}$ above the ground and plant losses were determined. The plant was designated as dead if no living tissue was detected at $5 \mathrm{~cm}$ above the ground.

Chemical analysis

Plant material was collected at the end of the growing season (December 2016 and 2017). Stems were collected from ten randomly chosen plants. Plant material was dried and minced, and chemical analysis was performed:

Crude ash - determined by burning of $2 \mathrm{~g}$ plant material at $600^{\circ} \mathrm{C}$ in an electric furnace. After loss on ignition the crucibles were placed in a desiccator to cool down, and then weighed to the nearest $0.001 \mathrm{~g}$

The Kjeldahl method using the Kjeltec apparatus was applied for total nitrogen determination

Potassium and calcium concentrations were determined by flame photometry using Flapho 4, [Carl Zeiss Jena]

Phosphorus concentration was determined by a colometric method with vanadium and molybdenum reagents using Spekol 10 [Carl Zeiss Jena]

Magnesium concentration was determined by a colometric method with yellow titanium using Spekol 10 [Carl Zeiss Jena]

Statistical Analysis 
Five years (2013-2017) of one-factor field experiment was established with the use of a random blocks method. The study was based on rigorous 1-factor field trials. The study compared weed assessments, morphological features, yield and chemical composition of: a) basket willow in monoculture without nitrogen fertilization, $b$ ) basket willow in undersowing cultivation with white clover and c) basket willow monoculture fertilized with nitrogen at a dose of $50 \mathrm{~kg} \mathrm{ha}^{-1}$. The area of plots was $12 \mathrm{~m}^{2}$ with 4 replications of each treatment.

All examined parameters were statistically evaluated, using variance analysis, at a 0.05 level of confidence. Plant mortality variations between treatments were compared using data from square root transformations. The conversion was performed in order to meet the assumptions of the standard normal distribution. The results were statistically analysed using STATISTICA 13.0 PL. Homogeneous groups were determined by Tukey's multiple range test using consecutive letters starting from "a" - the most beneficial value - to "e" - least beneficial in terms of economic value.

\section{Results And Discussion}

Weed assessments

Weed infestation has a significant effect on yield and plant mortality [29]. In a study carried out by Welc et al. [30] weed competition reduced aboveground biomass production on average by $36 \%$. In our own research for the first two years the weed flora was dominated by: Elymus repens (L.) Gould, Thlaspi arvense L., Viola arvensis Murr. and Chenopodium album L. In the next few years the occurrence of perennial weeds such as the one weed increased: Elymus repens, Artemisia vulgaris L., Urtica dioica L., Solidago canadensis L., Achillea millefolium L., Taraxacum officinale F.H. Wigg. Also Albertsson et al [31] noticed that the weed flora was initially dominated by annuals for the first two years, but became dominated by perennial weeds during the following years. During the field experiment the number and dry mass of weed decreased in 2013-2015. Also in the Edelfeldt et al. [32] study a higher weed biomass was obtained on plots that were not shaded. The lowest weed count was noted with the undersowing cultivation of willow and white clover. Similar results have been reported by other authors [33]. The largest dry mass of weeds was achieved on surfaces fertilized with nitrogen and the lowest on plots with white clover (Table 1). Fertilization may instead benefit weeds more than willow resulting in an increased competitive ability and a high relative growth rate for the weeds. The nitrogen levels had no significant effect on willow yield in a two-year study by Balasus et al. [34]. In another study [32], in the first year fertilization increased weed biomass growth by $46 \%$ suggesting that weeds are more responsive to fertilization than willow.

Plant mortality assessments

By the second 3-year harvest willow survival was still over $80 \%$ in the McCracken et al [35] research. In our own research $83 \%$ of the planted plants survived within 5 years. The number of plants $\mathrm{m}^{-2}$ decreased significantly in the study years, but no significant differences were found in the number of plants dying in 
different cultivation systems. Willow loss mainly occurred in the first year after the experiment had been established. The lowest rainfall was recorded in 2015 [see supplementary online material Table S3], which resulted in a higher number of withered willow plants than in the previous year. Willow plants produced on average about 3 shoots from one cut (Table 2). In the research by Hangs et al. [36], where the willow plants were cut down after the first year after planting, the number of shoots per plant was $2-3$ times higher than in that in our own experiment. There was no observed year-on-year influence on the number of shoots plant ${ }^{-1}$ and shoots $\mathrm{m}^{-2}$ (Table 2). The highest number of shoots plant ${ }^{-1}$ and shoots $\mathrm{m}^{-2}$ was obtained by growing willow in monoculture without nitrogen fertilization and the lowest by growing willow and white clover in undersowing cultivation. Willow density in this cultivation system should be increased compared to that in the willow monoculture.

\section{Morphological traits}

The stem diameter, plant height and number of shoots were found to be significant factors variable for willow biomass production [32]. The highest plant height increase was observed in the second year of the study. Regardless of the cultivation system, five years after planting the willow plants reached a height of more than $5 \mathrm{~m}$ and diameter of about $40 \mathrm{~mm}$ and the differences between the cultivation systems were negligible (Table 3, Fig. 1). Also the volume of trees fertilized with easily soluble fertilizers was no different from those fertilized with controlled-release fertilizers in the research by Brown and van den Driessche [37]. Sevel et al. [38] measured the diameter of 3-year-old shoots as being from 18.1 to 27.2 $\mathrm{mm}$ compared to the $25.8 \mathrm{~mm}$ observed in the own study (Table 3).

Mild temperatures and frequent rainfall are suitable conditions for growing willows. Willows have very high evapotranspiration requirements and in Sweden for optimal growth at mid-summer 5-6 $\mathrm{mm}$ of available water per day are needed [39]. Sufficient precipitation was recorded only in June 2013. In 2015 because of the lowest precipitation the lowest plant height increases were noticed except for first year trial (Table 3), [see supplementary online material Table S3]. In the reported experiments [22] it was observed that during the first 2 months after ploughing of 34-day old clover willow grew better in a pure stand. In the own trial we observed that the plant height in undersowing cultivation was higher than in the non-fertilized plants. However, the highest plant height was observed on plots where nitrogen fertilization was applied (Table 3).

There were the least number of shoots $\mathrm{m}^{-2}$ and shoots plant ${ }^{-1}$ in undersowing cultivation (Table 2). However, the higher accessibility of light and nutrients later meant that the dry mass of willow shoots in this cultivation was greater and the dry mass of plants did not varied between the different cultivation systems (Fig. 2). The dry mass in fresh plant mass was about 50\% (Table 5).

A regression analysis confirmed the presence of a significant correlation between the diameter of shoots, height of plants and dry mass of the main shoot (Table 4), [see supplementary online material Table S4]. Similar to the study by Krzyżaniak [40], a correlation was observed between the height of the main shoot 
and its diameter. A significant correlation $\left(r^{2}=0.86\right)$ between age and diameter was found in one study [41] by means of regression analysis in Sigma Plot 12.3

Yield of fresh and dry mass of willow

Willow can yield $20 \mathrm{Mg} \mathrm{ha}^{-1}$ under optimal conditions [42]. Based on the experience of other authors, the

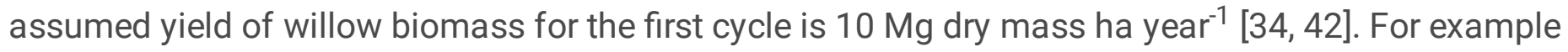
yields are given $9.1 \mathrm{mg} \mathrm{ha}^{-1}$ in the UK [43], in Swedish 7 dry mass ha year ${ }^{-1}$. In other research $[44,45]$ yield in Poland was higher compared to my field experiment. The subsequent rotations grow faster because the willow root system is already established [46]. Total dry mass of willow in undersowing cultivation with white clover was not significantly different from the total dry mass of willow under the control treatment in own study (Table 5). Similar results were obtained by Arevalo et al. (Arevalo i wsp. 2005) after several months of growing S. sachalinensis and S. discolor with white clover. However, in our own study the yield of fresh mass was significantly lower in willow with white clover than in monoculture (Table 5).

Chemical composition and uptake of macronutrients in willow plants

Similar to Schroeder et al. [47] the ash content was approximately $16 \mathrm{~g} \mathrm{~kg}^{-1}$ dry mass. The nitrogen content was the highest in the undersowing cultivation (Fig. 3) what shows that the willow has absorbed additional nitrogen taken up by the bacteria in symbiosis in white clover. Labrecque and Teodorescu [48] suggest that on sites where soil nitrogen content is high willows have a lower response to fertilization. In contrast to nitrogen the potassium content was lower in our research than in Sevel [38]. The P content was comparable to the results obtained by Jama-Rodzeńska et al. [49]. The nitrogen to phosphorus to potassium to calcium to magnesium ratios in the whole plant were as follows: 1.0:0.1:0.2:0.4:0.1 (Fig. 3). In all instances the wood had less ash and macroelements than the phloem (Table 6). On average the proportions of nitrogen to phosphorus, potassium, calcium and magnesium in the wood were 1.0:0.2:0.2:0.4:0.2 and in the phloem 1.0:0.1:0.2:0.5:0.1. The ratio of wood dry mass to phloem dry mass in undersowing cultivation and nitrogen fertilization was 3.9:1 and for the control 3.91:1. Nitrogen fertilization (and production of nitrogenous fertilisers) and combustion of biomass with high nitrogen content adversely affects the climate and human health [50]. Therefore taking into account the protection of the environment and human health the best way of cultivation turned out to be a willow monoculture without nitrogen fertilization.

Harvesting was the main factor responsible for the net export of nutrients [38] and should be taken into account for the determination of fertilizer doses. In the experiment by Labrecque and Teodorescu [48] after the completion of 3 years of willow rotation and depending on the fertilization of sewage sludge and soil, the nitrogen intake amounted to 50,3-176,2; phosphorus 5,9-20,6; potassium 16,7-71,3; calcium 49,8-96,5 and magnesium 4,3-13,9 $\mathrm{kg} \mathrm{ha}^{-1}$ year $^{-1}$. Nitrogen and phosphorus uptake on sandy soils was similar and potassium and calcium uptake was higher [48] than in my own research. In our own studies the uptake of nitrogen and calcium was similar, magnesium higher and potassium lower than in 
Sevel studies [38]. In my field experiment in undersowing cultivation the accumulation of crude ash and calcium was lower than in monoculture (Fig. 4). Less raw ash and calcium elevation may lead to a smaller decrease in soil pH, which is beneficial on light soils in Poland.

\section{Conclusion}

White clover grown together with willow contributed to the reduction of willow shoots both $\mathrm{pcs} \mathrm{m}^{-2}$ and pcs plant ${ }^{-1}$. Undersowing of two selected species also resulted in the highest dry mass of willow shoots taking into account the lower competition for daylight and nutrients. The dry mass of willow $\left(\mathrm{Mg} \mathrm{ha}^{-1}\right)$ in undersowing system cultivation and nitrogen fertilization did not show positive effects compared to cultivation in monoculture without fertilization. This might suggest that nitrogen fertilization is not an essential factor for willow growth in the first years after planting. Willow shoots grown together with clover were characterized by higher nitrogen content compared to monoculture. Lack of nitrogen fertilization in the first years after planting reduces the cost of establishing a plantation and is beneficial to the environment. The results of the experiment indicate that the lower number of willow shoots $\mathrm{m}^{-2}$ at an annual rainfall of $390-730 \mathrm{~mm}$ in the undersowing-with-clover system led to competition between both species for water resources. Therefore, this method of cultivation may turn out to be risky in case of low precipitation.

\section{Declarations}

- Funding (information that explains whether and by whom the research was supported)

\section{- Not applicable for that section}

- Availability of data and materials

- Upon request, with the consent of the superiors

- Authors' contributions

\section{Waldemar Helios - $100 \%$}

- Ethics approval and consent to participate:

\section{- Not applicable for that section}

- Consent for publication:

- Author agree to publication of the submitted manuscript even after amendments arising from the peerreview

- Competing interests: 


\section{- Not applicable for that section}

\section{References}

1. Keoleian GA, Volk TA (2005) Renewable Energy from Willow Biomass Crops. Life Cycle Energy, Environmental and Economic Performance. Critical Reviews in Plant Sciences 24(5-6): 385-406. doi: $10.1080 / 07352680500316334$

2. Verwijst T, Lundkvist A, Edelfeldt S et al. (2013) Development of Sustainable Willow Short Rotation Forestry in Northern Europe. In: Matovic MD (ed) Biomass Now - Sustainable Growth and Use. InTech

3. Mekala NK, Potumarthi R, Baadhe RR et al. (2013) Chapter 1 - Current Bioenergy Researches. Strengths and Future Challenges. In: Gupta VG (ed) Bioenergy Research. Advances and Applications. Elsevier, Amsterdam, pp 1-21

4. Clifton-Brown J, Hastings A, Mos $M$ et al. (2017) Progress in upscaling Miscanthus biomass production for the European bio- economy with seed based hybrids. GCB Bioenergy: n/a-n/a. doi: $10.1111 /$ gcbb. 12357

5. Hansen EM, Christensen BT, Jensen LS et al. (2004) Carbon sequestration in soil beneath long-term Miscanthus plantations as determined by 13C abundance. Biomass and Bioenergy 26(2): 97-105. doi: 10.1016/S0961-9534(03)00102-8

6. Caputo J, Balogh SB, Volk TA et al. (2014) Incorporating Uncertainty into a Life Cycle Assessment (LCA) Model of Short-Rotation Willow Biomass (Salix spp.) Crops. Bioenerg. Res. 7(1): 48-59. doi: 10.1007/s12155-013-9347-y

7. Clifton-Brown JC, Breuer J, Jones MB (2007) Carbon mitigation by the energy crop, Miscanthus. Global Change Biol 13(11): 2296-2307. doi: 10.1111/j.1365-2486.2007.01438.x

8. Mc Laughlin RA, Pope PE, Hansen EA (1985) Nitrogen Fertilization and Ground Cover in a Hybrid Poplar Plantation. Effects on Nitrate Leaching. Journal of Environmental Quality 14(2): 241-245. doi: 10.2134/jeq1985.00472425001400020017x

9. McLaughlin SB, Walsh ME (1998) Evaluating environmental consequences of producing herbaceous crops for bioenergy. Biomass and Bioenergy 14(4): 317-324. doi: 10.1016/S0961-9534(97)10066-6

10. Lemus R, Lal R (2005) Bioenergy Crops and Carbon Sequestration. Critical Reviews in Plant Sciences 24(1): 1-21. doi: 10.1080/07352680590910393

11. Stolarski M, Szczukowski S, Tworkowski J et al. (2008) Productivity of seven clones of willow coppice in annual and quadrennial cutting cycles. Biomass and Bioenergy 32(12): 1227-1234. doi: 10.1016/j.biombioe.2008.02.023

12. Stolarski MJ, Krzyżaniak M, Szczukowski S et al. (2015) Effect of Increased Soil Fertility on the Yield and Energy Value of Short-Rotation Woody Crops. Bioenerg. Res. 8(3): 1136-1147. doi: 10.1007/s12155-014-9567-9

13. Verwijst T (2001) Willows. An underestimated resource for environment and society. The Forestry Chronicle 77(2): 281-285. doi: 10.5558/tfc77281-2 
14. Serapiglia MJ, Cameron KD, Stipanovic AJ et al. (2013) Yield and Woody Biomass Traits of Novel Shrub Willow Hybrids at Two Contrasting Sites. Bioenerg. Res. 6(2): 533-546. doi: 10.1007/s12155012-9272-5

15. Andrews M, Scholefield D, Abberton MT et al. (2007) Use of white clover as an alternative to nitrogen fertiliser for dairy pastures in nitrate vulnerable zones in the UK. Productivity, environmental impact and economic considerations. Ann Applied Biology 151(1): 11-23. doi: 10.1111/j.17447348.2007.00137.x

16. Heilman P, Norby RJ (1998) Nutrient cycling and fertility management in temperate short rotation forest systems. Biomass and Bioenergy 14(4): 361-370. doi: 10.1016/S0961-9534(97)10072-1

17. Kort J, Collins M, Ditsch D (1998) A review of soil erosion potential associated with biomass crops. Biomass and Bioenergy 14(4): 351-359. doi: 10.1016/S0961-9534(97)10071-X

18. Mann L, Tolbert V (2000) Soil Sustainability in Renewable Biomass Plantings. AMBIO: A Journal of the Human Environment 29(8): 492-498. doi: 10.1579/0044-7447-29.8.492

19. Malik RK, Green TH, Brown GF et al. (2000) Use of cover crops in short rotation hardwood plantations to control erosion. Biomass and Bioenergy 18(6): 479-487. doi: 10.1016/S0961-9534(00)00016-7

20. Fabio ES, Smart LB (2018) Effects of nitrogen fertilization in shrub willow short rotation coppice production - a quantitative review. GCB Bioenergy 10(8): 548-564. doi: 10.1111/gcbb.12507

21. Densmore RV, Neiland BJ, Zasada JC et al. (1987) Planting Willow for Moose Habitat Restoration on the North Slope of Alaska, U.S.A. Arctic and Alpine Research 19(4): 537-543

22. Arevalo CBM, Drew AP, Volk TA (2005) The effect of common Dutch white clover (Trifolium repens L.), as a green manure, on biomass production, allometric growth and foliar nitrogen of two willow clones. Biomass and Bioenergy 29(1): 22-31

23. Teasdale JR (1996) Contribution of Cover Crops to Weed Management in Sustainable Agricultural Systems. Journal of Production Agriculture 9(4): 475-479. doi: 10.2134/jpa1996.0475

24. Helios W, Kozak M, Kotecki A et al. (2020) Follow-up effect of white clover (Trifolium repens L.) intercropping system on biomass and morphology of willow (Salix viminalis L.). Renew. Agric. Food Syst. 51: 1-12. doi: 10.1017/S1742170519000498

25. Boller BC, Nösberger J (1987) Symbiotically fixed nitrogen from field-grown white and red clover mixed with ryegrasses at low levels of $15 \mathrm{~N}$-fertilization. Plant Soil 104(2): 219-226. doi: 10.1007/BF02372535

26. Edmeades DC, Goh KM (2012) Symbiotic nitrogen fixation in a sequence of pastures of increasing age measured by a $15 \mathrm{~N}$ dilution technique. New Zealand Journal of Agricultural Research 21(4): 623-628. doi: 10.1080/00288233.1978.10427458

27. Malik R (2001) Biomass production of short-rotation bioenergy hardwood plantations affected by cover crops. Biomass and Bioenergy 21(1): 21-33. doi: 10.1016/S0961-9534(01)00017-4

28. Cogliastro A, Gagnon D, Coderre D et al. (1990) Response of seven hardwood tree species to herbicide, rototilling, and legume cover at two southern Quebec plantation sites. Can. J. For. Res. 20(8): 1172-1182. doi: 10.1139/x90-156

Page $11 / 18$ 
29. Albertsson J, Hansson D, Bertholdsson N-O et al. (2014) Site-related set-back by weeds on the establishment of 12 biomass willow clones. Weed Res 54(4): 398-407. doi: 10.1111/wre.12086

30. Welc M, Lundkvist A, Verwijst T (2017) Effects of Cutting Phenology (Non-dormant Versus Dormant) on Early Growth Performance of Three Willow Clones Grown Under Different Weed Treatments and Planting Dates. Bioenerg. Res. 10(4): 1094-1104. doi: 10.1007/s12155-017-9871-2

31. Albertsson J, Verwijst T, Hansson D et al. (2014) Effects of competition between short-rotation willow and weeds on performance of different clones and associated weed flora during the first harvest cycle. Biomass and Bioenergy 70: 364-372. doi: 10.1016/j.biombioe.2014.08.003

32. Edelfeldt S, Lundkvist A, Forkman J et al. (2016) Establishment and Early Growth of Willow at Different Levels of Weed Competition and Nitrogen Fertilization. Bioenerg. Res. 9(3): 763-772. doi: $10.1007 / \mathrm{s} 12155-016-9723-5$

33. Adiele JG, Volk TA (2013) Developing live cover crop systems for willow (Salix spp.)bioenergy crop. Sky. J. Soil. Sci. Environ. Manage 2(9): 84-100

34. Balasus A, Bischoff W-A, Schwarz A et al. (2012) Nitrogen fluxes during the initial stage of willows and poplars in short-rotation coppices. Journal of Plant Nutrition and Soil Science 175(5): 729-738. doi: $10.1002 / j p l n .201100346$

35. McCracken AR, Walsh L, Moore PJ et al. (2011) Yield of willow (Salix spp.) grown in short rotation coppice mixtures in a long-term trial. Ann Applied Biology 159(2): 229-243. doi: 10.1111/j.17447348.2011.00488.x

36. Hangs RD, Stevenson FC, Schoenau JJ et al. (2013) Measuring Harvestable Biomass in ShortRotation Willow Bioenergy Plantations Using Light Attenuation. Bioenerg. Res. 6(1): 83-90. doi: 10.1007/s12155-012-9238-7

37. Brown KR, van den Driessche R (2002) Growth and nutrition of hybrid poplars over 3 years after fertilization at planting. Can. J. For. Res. 32(2): 226-232. doi: 10.1139/x01-191

38. Sevel L, Ingerslev M, Nord-Larsen T et al. (2014) Fertilization of SRC Willow, II. Leaching and Element Balances. Bioenerg. Res. 7(1): 338-352. doi: 10.1007/s12155-013-9370-z

39. Perttu KL (1999) Environmental and hygienic aspects of willow coppice in Sweden. Biomass and Bioenergy 16(4): 291-297. doi: 10.1016/S0961-9534(98)00012-9

40. Krzyżaniak M, Stolarski MJ, Szczukowski S et al. (2015) Willow biomass obtained from different soils as a feedstock for energy. Industrial Crops and Products 75(1): 114-121. doi:

10.1016/j.indcrop.2015.06.030

41. Mirck J, Schroeder W (2013) Composition, Stand Structure, and Biomass Estimates of "Willow Rings" on the Canadian Prairies. Bioenerg. Res. 6(3): 864-876. doi: 10.1007/s12155-013-9338-z

42. Mitchell CP (1995) New cultural treatments and yield optimisation. Biomass and Bioenergy 9(15): 11-34. doi: 10.1016/0961-9534(95)00076-3

43. Aylott MJ, Casella E, Tubby I et al. (2008) Yield and spatial supply of bioenergy poplar and willow short-rotation coppice in the UK. The New phytologist 178(2): 358-370. doi: 10.1111/j.14698137.2008.02396.x 
44. Szczukowski S, Stolarski M, Tworkowski J et al. (2011) Productivity of willow coppice plants grown in short rotations. Plant Soil Environ. 51(No. 9): 423-430. doi: 10.17221/3607-PSE

45. Szczukowski S, Tworkowski J, Klasa A et al. (2011) Productivity and chemical composition of wood tissues of short rotation willow coppice cultivated on arable land. Plant Soil Environ. 48(No. 9): 413417. doi: $10.17221 / 4389-P S E$

46. Heller MC, Keoleian GA, Volk TA (2003) Life cycle assessment of a willow bioenergy cropping system. Biomass and Bioenergy 25(2): 147-165. doi: 10.1016/S0961-9534(02)00190-3

47. Schroeder W, Kort J, Savoie P et al. (2009) Biomass Harvest from Natural Willow Rings around Prairie Wetlands. Bioenerg. Res. 2(3): 99-105. doi: 10.1007/s12155-009-9040-3

48. Labrecque M, Teodorescu TI (2003) High biomass yield achieved by Salix clones in SRIC following two 3-year coppice rotations on abandoned farmland in southern Quebec, Canada. Biomass and Bioenergy 25(2): 135-146. doi: 10.1016/S0961-9534(02)00192-7

49. Jama-Rodzeńska A, Bocianowski J, Nowak W et al. (2016) The influence of communal sewage sludge on the content of macroelements in the stem of selected clones of willow (Salix viminalis L.). Ecological Engineering 87: 212-217. doi: 10.1016/j.ecoleng.2015.11.046

50. Scholz V (2002) The growth productivity, and environmental impact of the cultivation of energy crops on sandy soil in Germany. Biomass and Bioenergy 23(2): 81-92. doi: 10.1016/S09619534(02)00036-3

\section{Tables}

Table1 Dry weight and number of weeds (mean for cultivation system and years)

\begin{tabular}{|c|c|c|c|}
\hline Years & Cultivation willow & $\begin{array}{c}\text { Number of weeds } \\
{\left[\mathrm{pcs} / \mathrm{m}^{2}\right]}\end{array}$ & $\begin{array}{l}\text { Dry weight of weeds } \\
\qquad\left[\mathrm{g} / \mathrm{m}^{2}\right]\end{array}$ \\
\hline \multicolumn{2}{|l|}{2013} & $17.7 \mathrm{~b}$ & $368 \mathrm{~b}$ \\
\hline \multicolumn{2}{|l|}{2014} & $15.4 \mathrm{ab}$ & $257 \mathrm{ab}$ \\
\hline \multicolumn{2}{|l|}{2015} & $13.7 \mathrm{a}$ & $188 \mathrm{a}$ \\
\hline \multicolumn{2}{|l|}{2016} & $14.0 \mathrm{a}$ & $202 \mathrm{ab}$ \\
\hline \multicolumn{2}{|l|}{2017} & $13.7 \mathrm{a}$ & $213 \mathrm{ab}$ \\
\hline \multicolumn{2}{|c|}{ LSD $(\alpha=0.05)$} & 1.56 & 109.3 \\
\hline \multicolumn{2}{|r|}{ Willow monoculture without nitrogen fertilisation } & $16.6 \mathrm{~b}$ & $262 \mathrm{~b}$ \\
\hline \multicolumn{2}{|r|}{ Undersowing cultivation with white clover } & $12.0 \mathrm{a}$ & $135 \mathrm{a}$ \\
\hline \multicolumn{2}{|r|}{ Monoculture with nitrogen fertilisation } & $16.0 \mathrm{~b}$ & $339 b$ \\
\hline \multicolumn{2}{|c|}{ LSD $(\alpha=0.05)$} & 1.21 & 84.7 \\
\hline
\end{tabular}

Different letters indicate significant differences between treatments (Tukey's multiple range test).

Table 2 Plant density in undersowing and monoculture cultivation (mean for cultivation system and years) 


\begin{tabular}{|c|c|c|c|c|c|}
\hline \multirow[t]{2}{*}{ Cultivation system } & \multirow[t]{2}{*}{ Number of plants $\left[\mathrm{pcs} / \mathrm{m}^{2}\right]$} & \multicolumn{2}{|c|}{ Plant mortality* } & \multicolumn{2}{|c|}{ Number of shoots } \\
\hline & & $\mathrm{a}$ & $\mathrm{b}$ & {$\left[\mathrm{pcs} / \mathrm{m}^{2}\right]$} & [pcs/plant] \\
\hline 2013 & $1.48 \mathrm{a}$ & 11.43 & $3.15 \mathrm{~b}$ & $4.29 \mathrm{a}$ & $2.89 \mathrm{a}$ \\
\hline 2014 & $1.47 \mathrm{a}$ & 0.84 & $0.37 a$ & $4.15 \mathrm{a}$ & $2.83 a$ \\
\hline 2015 & $1.34 \mathrm{ab}$ & 8.26 & $2.01 \mathrm{ab}$ & $4.04 \mathrm{a}$ & $3.01 \mathrm{a}$ \\
\hline 2016 & $1.32 \mathrm{ab}$ & 1.65 & $0.64 \mathrm{a}$ & $3.82 \mathrm{a}$ & $2.87 \mathrm{a}$ \\
\hline 2017 & $1.23 \mathrm{~b}$ & 7.55 & $1.74 \mathrm{ab}$ & $3.97 \mathrm{a}$ & $3.23 \mathrm{a}$ \\
\hline $\operatorname{LSD}(\alpha=0.05)$ & 0.120 & - & 1.316 & NS & NS \\
\hline Willow monoculture without nitrogen fertilisation & $1.40 \mathrm{a}$ & 4.93 & $1.35 \mathrm{a}$ & $5.02 \mathrm{a}$ & $3.62 \mathrm{a}$ \\
\hline Undersowing cultivation with white clover & $1.32 \mathrm{a}$ & 7.86 & $2.09 \mathrm{a}$ & $2.74 \mathrm{c}$ & $2.08 \mathrm{c}$ \\
\hline Monoculture with nitrogen fertilisation & $1.37 \mathrm{a}$ & 5.05 & $1.31 \mathrm{a}$ & $4.40 \mathrm{~b}$ & $3.20 \mathrm{~b}$ \\
\hline $\operatorname{LSD}(\alpha=0.05)$ & NS & - & NS & 0.454 & 0.329 \\
\hline
\end{tabular}

NS - difference is not significant

Different letters indicate significant differences between treatments (Tukey's multiple range test).

*a - \% of dead plants, b - Transformation of dead plants by root formation.

Table 3 Influence of undersowing cultivation and nitrogen fertilization on morphological traits of willow plant (mean for cultivation system and years)

\begin{tabular}{|c|c|c|c|c|c|}
\hline Years & Cultivation system & $\begin{array}{l}\text { Height of plants at the } \\
\text { end of vegetation }[\mathrm{cm}]\end{array}$ & $\begin{array}{l}\text { Yearly increase in } \\
\text { the height of plants } \\
{[\mathrm{cm}]}\end{array}$ & $\begin{array}{c}\text { Diameter of shoots after } \\
\text { the end of vegetation } \\
{[\mathrm{mm}]}\end{array}$ & $\begin{array}{c}\text { Yearly increase in } \\
\text { shoot diameter } \\
{[\mathrm{mm}]}\end{array}$ \\
\hline 2013 & & $79 e$ & $79 b$ & $10.0 \mathrm{e}$ & $10.0 \mathrm{a}$ \\
\hline 2014 & & $221 d$ & $142 \mathrm{a}$ & $18.3 d$ & 8.3a \\
\hline 2015 & & $307 \mathrm{c}$ & $85 b$ & $25.8 \mathrm{c}$ & $7.5 \mathrm{a}$ \\
\hline 2016 & & $407 \mathrm{~b}$ & $100 \mathrm{ab}$ & $32.6 \mathrm{~b}$ & $6.8 \mathrm{a}$ \\
\hline 2017 & & $519 a$ & $113 a b$ & $41.5 \mathrm{a}$ & $8.9 \mathrm{a}$ \\
\hline \multicolumn{2}{|c|}{$\operatorname{LSD}(\alpha=0.05)$} & 29.6 & 34.5 & 3.98 & NS \\
\hline & $\begin{array}{l}\text { Willow monoculture } \\
\text { without nitrogen } \\
\text { fertilisation }\end{array}$ & 291b & $102 \mathrm{a}$ & $24.8 \mathrm{a}$ & $8.1 \mathrm{a}$ \\
\hline & $\begin{array}{l}\text { Undersowing } \\
\text { cultivation with white } \\
\text { clover }\end{array}$ & $305 a b$ & $104 a$ & $25.3 a$ & $8.4 \mathrm{a}$ \\
\hline & $\begin{array}{l}\text { Monoculture with } \\
\text { nitrogen fertilisation }\end{array}$ & $324 a$ & $105 a$ & $26.8 \mathrm{a}$ & $8.4 \mathrm{a}$ \\
\hline \multicolumn{2}{|c|}{$\operatorname{LSD}(\alpha=0.05)$} & 22.9 & NS & NS & NS \\
\hline
\end{tabular}

NS - difference is not significant

Different letters indicate significant differences between treatments (Tukey's multiple range test).

Table 4 Correlation coefficients for the analysed traits

\begin{tabular}{|c|c|c|c|c|c|}
\hline \multirow[t]{2}{*}{ Cultivation system } & \multirow[t]{2}{*}{ Mean } & \multirow{2}{*}{$\begin{array}{l}\text { Standard } \\
\text { deviation }\end{array}$} & \multicolumn{3}{|c|}{ Correlation coefficients } \\
\hline & & & $\begin{array}{c}\text { Dry mass of the main } \\
\text { shoot }\end{array}$ & $\begin{array}{l}\text { Diameter of } \\
\text { shoots }\end{array}$ & $\begin{array}{l}\text { Height of } \\
\text { plants }\end{array}$ \\
\hline $\begin{array}{l}\text { Dry mass of the main } \\
\text { shoot }\end{array}$ & $1187[\mathrm{~g}]$ & 605 & 1 & & \\
\hline Diameter of shoots & $39.5[\mathrm{~mm}]$ & 8.99 & 0.90 & 1 & \\
\hline Height of plants & $510[\mathrm{~cm}]$ & 100 & 0.74 & 0.75 & 1 \\
\hline
\end{tabular}


*All correlation coefficients are significant. Only 9 shoots in three replications were used to calculate the correlation factor.

Table 5 Comparison of yielding in monoculture and willow undersowing cultivation 5 years after planting

\begin{tabular}{lcccc}
\hline Cultivation system & \multicolumn{3}{c}{ Dry mass yield [Mg/ha] } & Fresh mass yield [Mg/ha] \\
\cline { 2 - 4 } & wood & phloem & total & \\
\hline Willow monoculture without nitrogen fertilisation & $36.8 \mathrm{a}$ & $9.4 \mathrm{a}$ & $46.2 \mathrm{a}$ & \\
Undersowing cultivation with white clover & $29.0 \mathrm{a}$ & $7.3 \mathrm{a}$ & $36.3 \mathrm{a}$ & $91.2 \mathrm{a}$ \\
Monoculture with nitrogen fertilisation & $35.7 \mathrm{a}$ & $9.0 \mathrm{a}$ & $44.7 \mathrm{a}$ & $71.1 \mathrm{~b}$ \\
\hline LSD $(\alpha=0.05)$ & $\mathrm{NS}$ & $\mathrm{NS}$ & $\mathrm{NS}$ & $90.5 \mathrm{a}$ \\
\hline
\end{tabular}

NS - difference is not significant

Different letters indicate significant differences between treatments (Tukey's multiple range test).

Table 6 Nutrient content in willow with two fertilising treatments and undersowing system in 2017

\begin{tabular}{|c|c|c|c|c|c|c|}
\hline \multirow[t]{2}{*}{ Cultivation system } & Crude ash & $\mathrm{N}$ & $\mathrm{P}$ & $\mathrm{K}$ & $\mathrm{Ca}$ & $\mathrm{Mg}$ \\
\hline & \multicolumn{6}{|c|}{$[\mathrm{g} / \mathrm{kg}]$} \\
\hline \multicolumn{7}{|l|}{ willow wood } \\
\hline Willow monoculture without nitrogen fertilisation & 7.2 & 3.9 & 0.7 & 0.8 & 1.4 & 0.7 \\
\hline Undersowing cultivation with white clover & 7.3 & 5.1 & 0.9 & 1.0 & 1.5 & 1.0 \\
\hline Monoculture with nitrogen fertilisation & 10.2 & 3.8 & 0.7 & 0.9 & 1.9 & 0.8 \\
\hline \multicolumn{7}{|l|}{ willow phloem } \\
\hline Willow monoculture without nitrogen fertilisation & 43.1 & 19.0 & 2.3 & 3.4 & 9.3 & 1.3 \\
\hline Undersowing cultivation with white clover & 47.5 & 20.2 & 1.7 & 3.6 & 8.4 & 0.9 \\
\hline Monoculture with nitrogen fertilisation & 47.9 & 20.0 & 2.1 & 3.7 & 9.7 & 1.8 \\
\hline
\end{tabular}

\section{Figures}

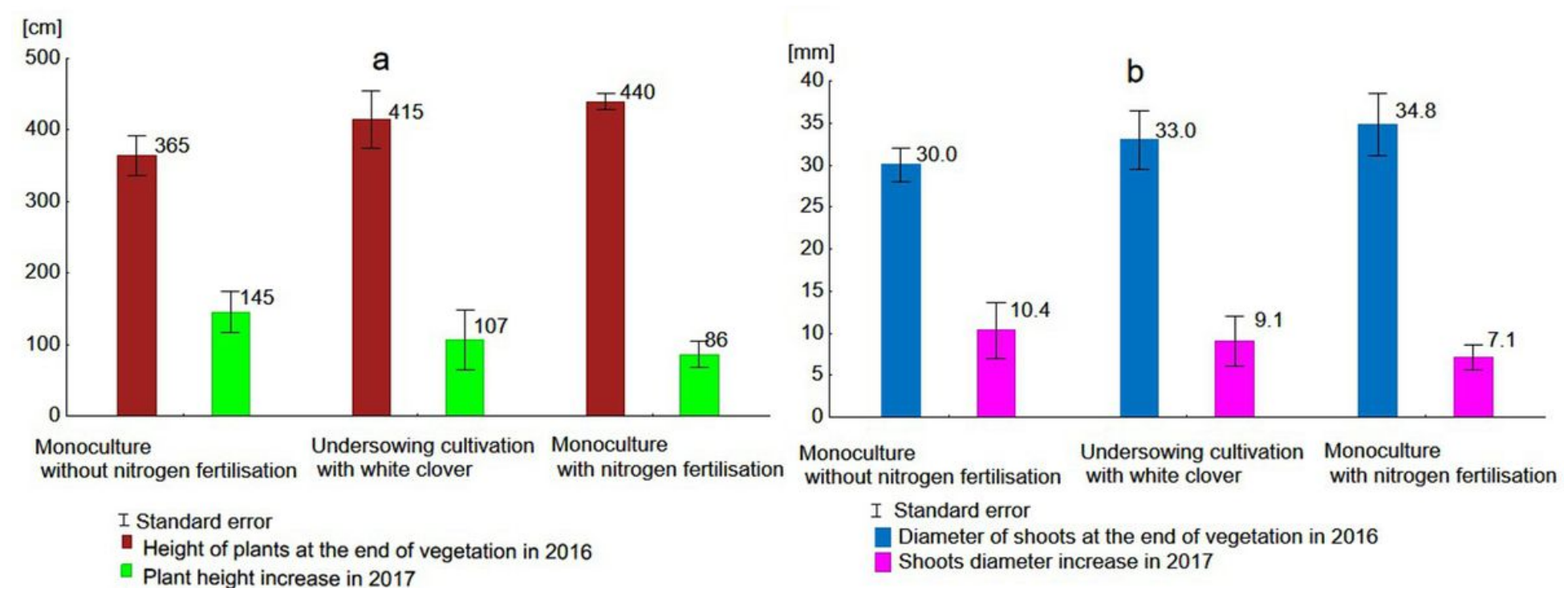

\section{Figure 1}




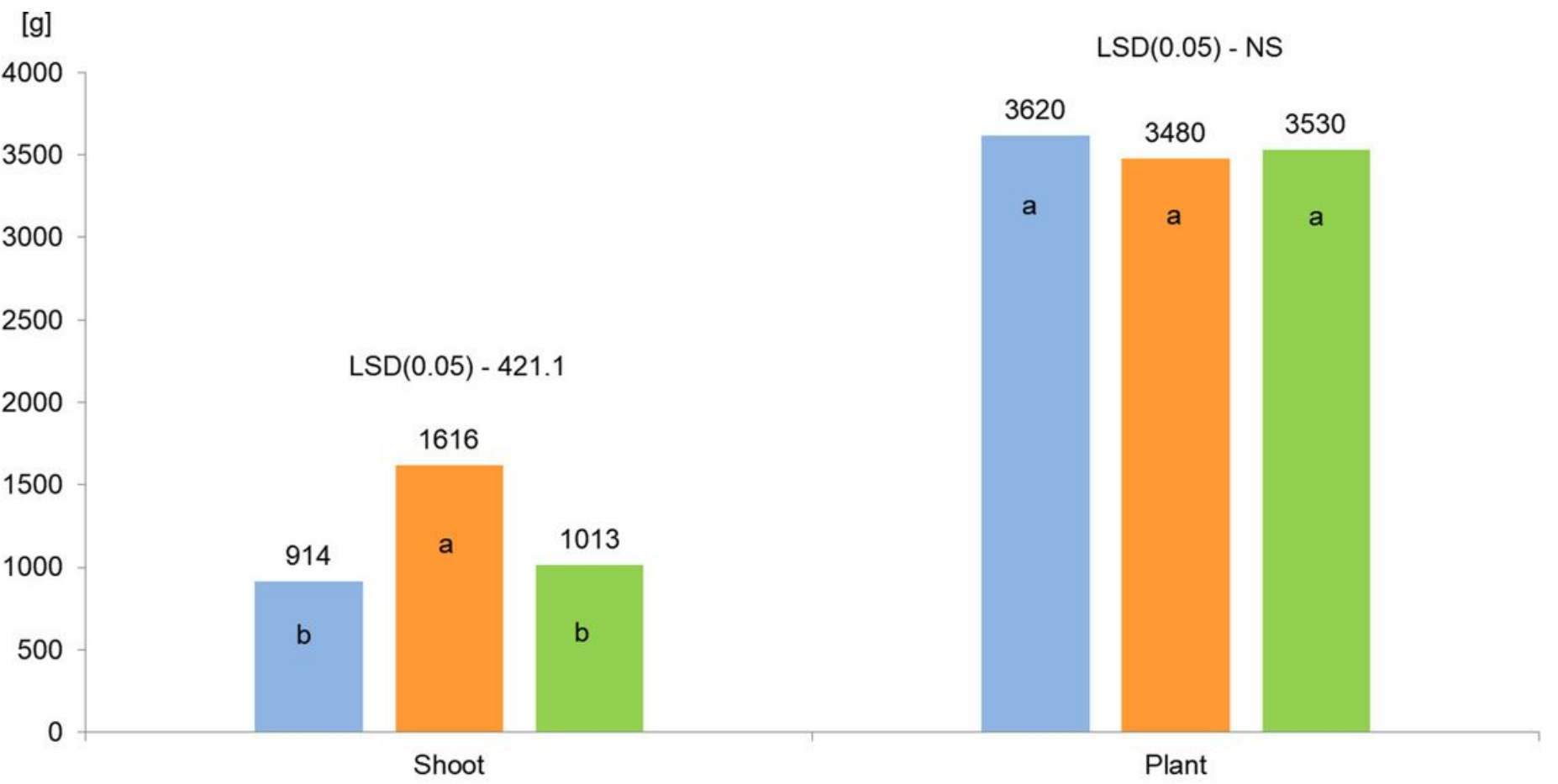

Willow monoculture without nitrogen fertilisation $\backsim$ Undersowing cultivation with white clover $\backsim$ Monoculture with nitrogen fertilisation

\section{Figure 2}

Influence of undersowing cultivation and nitrogen fertilization on the dry mass of 1 shoot and plants of willow plants NS - difference is not significant different letters indicate significant differences between treatments (Tukey's multiple range test). 


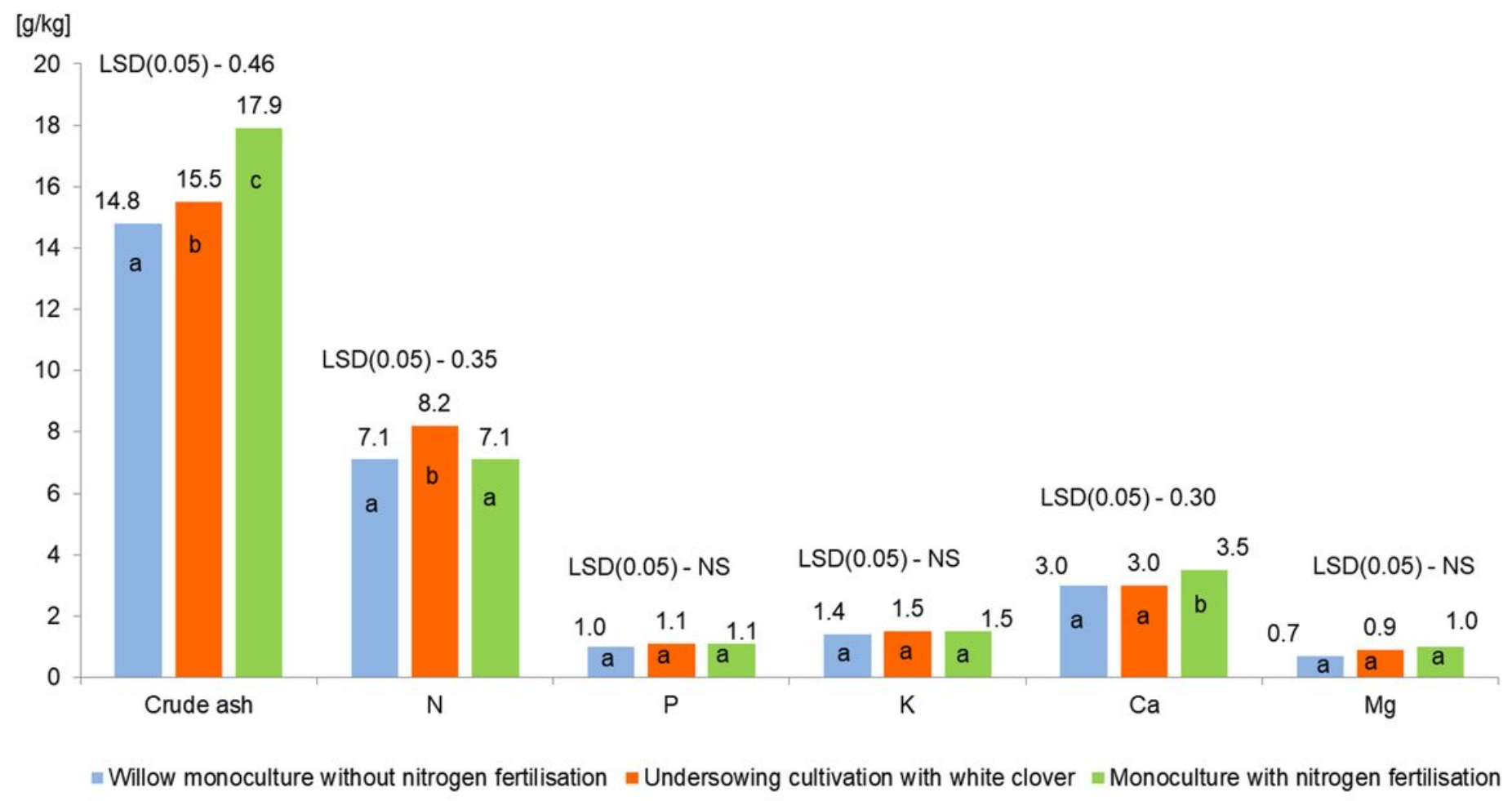

\section{Figure 3}

Nutrient content in whole willow plants with two fertilising treatments and undersowing system (average for 2016-2017) NS - difference is not significant different letters indicate significant differences between treatments (Tukey's multiple range test). 


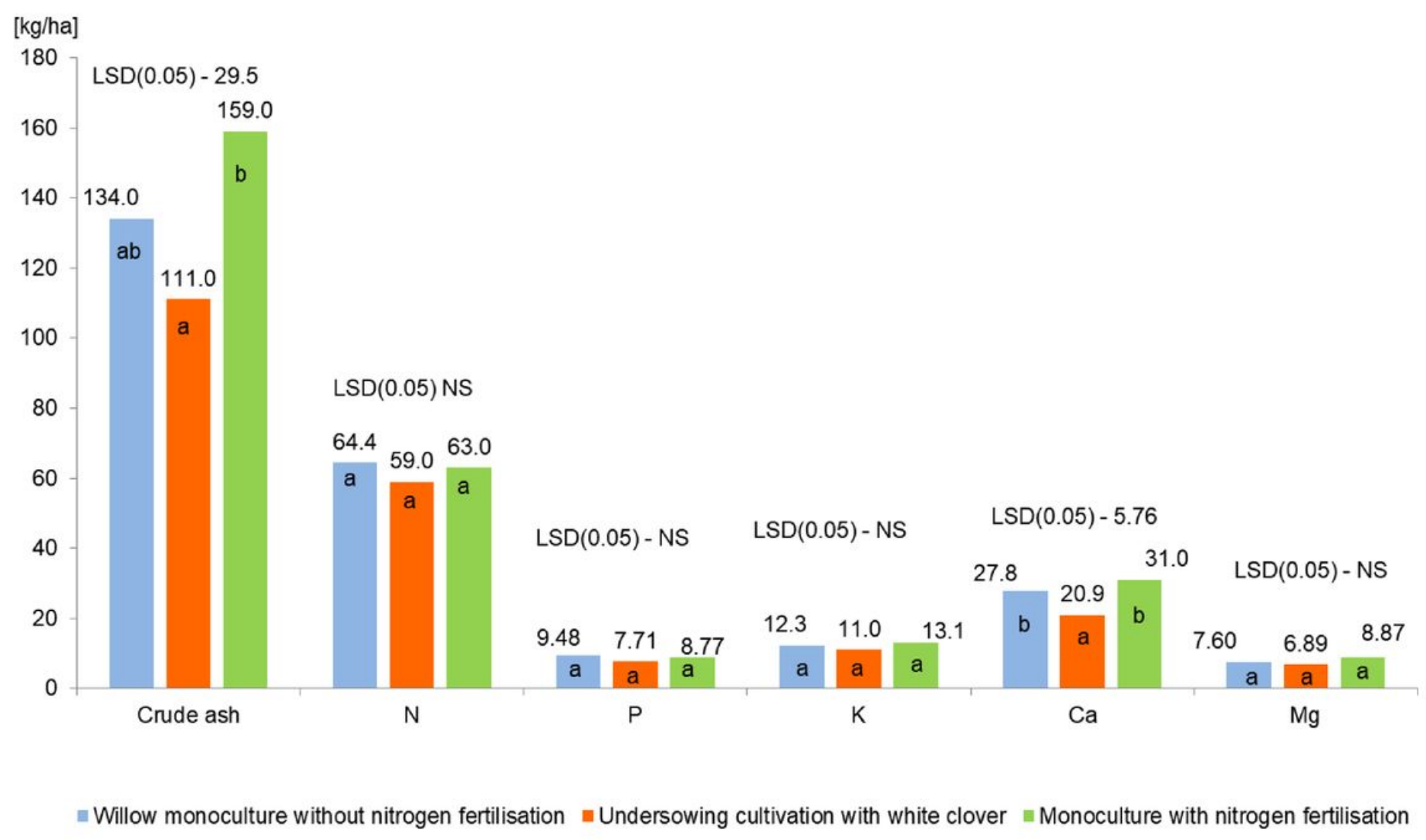

Figure 4

Annual nutrient uptake with two fertilising treatments and undersowing system NS - difference is not significant different letters indicate significant differences between treatments (Tukey's multiple range test).

\section{Supplementary Files}

This is a list of supplementary files associated with this preprint. Click to download.

- supplementaryonlinematerial.rar 